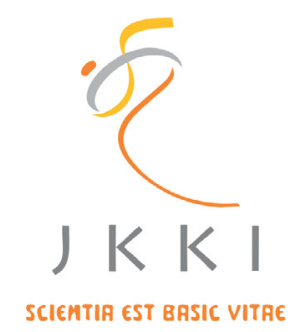

Jurnal Kedokteran dan Kesehatan Indonesia

Indonesian Journal of Medicine and Health

Journal homepage : www.journal.uii.ac.id/index.php/JKKI

\title{
Successful conversion of complete atrioventricular block to sinus rhythm without cardiac pacemaker: A case report
}

Handy Darmawan*1

${ }^{1}$ Emergency Department, Dr. Iskak General Hospital, Tulungagung, Indonesia

Case Report

\begin{tabular}{|c|c|}
\hline & ABSTRACT \\
\hline ARTICLE INFO & \multirow{6}{*}{$\begin{array}{l}\text { Complete atrioventricular (AV) block is a medical emergency, which is } \\
\text { related to cardiac arrest if left untreated. The insertion of permanent } \\
\text { cardiac pacemaker is strongly indicated for its treatment. However, on the } \\
\text { rarest occasion, this condition can be treated without a cardiac pacemaker. } \\
\text { A } 56 \text { year old male with a history of chronic kidney disease, was admitted } \\
\text { to our emergency department due to the decrease of consciousness. } \\
\text { Complete AV block and severe hypotension were detected. Laboratory } \\
\text { examination showed severe hyperkalemia and metabolic acidosis. } \\
\text { Unexpectedly, the cardiac rhythm was returned into sinus after the serial } \\
\text { correction of hyperkalemia using calcium gluconate, insulin, dextrose, } \\
\text { and bicarbonate sodium. This case illustrates that hyperkalemia can be a } \\
\text { reversible cause of complete AV block, which can be converted into sinus } \\
\text { rhythm without a cardiac pacemaker. Routine examination and correction } \\
\text { of hyperkalemia can be considered as the alternative initial management } \\
\text { before the insertion of the cardiac pacemaker. }\end{array}$} \\
\hline $\begin{array}{l}\text { Keywords: } \\
\text { Atrioventricular block, } \\
\text { hyperkalemia, } \\
\text { pacemaker }\end{array}$ & \\
\hline & \\
\hline DOI: 10.20885/IKKI.Vol10.Iss3.art12 & \\
\hline $\begin{array}{l}\text { History: } \\
\text { Received: August 27, } 2018 \\
\text { Accepted: November 28, } 2019 \\
\text { Online: December 30, } 2019\end{array}$ & \\
\hline $\begin{array}{l}\text { Copyright @2019 Authors. } \\
\text { This is an open access article } \\
\text { distributed under the terms } \\
\text { of the Creative Commons At- } \\
\text { tribution-NonCommercial } 4.0\end{array}$ & \\
\hline
\end{tabular}
International Licence (http:// creativecommons.org/licences/ by-nc/4.0/).

Blok atrioventrikuler (AV) total adalah kegawatdaruratan medis yang dapat menyebabkan henti jantung bila tidak mendapatkan terapi. Pemasangan alat pacu jantung permanen sangat direkomendasikan untuk tatalaksana kondisi ini. Namun, pada kasus yang langka, kondisi ini dapat diatasi tanpa menggunakan alat pacu jantung. Seorang laki-laki berusia 56 tahun dengan riwayat penyakit ginjal kronik, datang ke unit gawat darurat kami karena penurunan kesadaran. Blok AV total dan hipotensi berat terdeteksi pada pasien ini. Pemeriksaan laboratorium menunjukkan adanya hiperkalemia berat dan asidosis metabolik. Ternyata, irama jantung pasien ini kembali menjadi sinus setelah koreksi serial dari hiperkalemia menggunakan kalsium glukonat, insulin, dekstrosa, dan natrium bikarbonat.

Kasus ini menggambarkan bahwa hiperkalemia dapat menjadi penyebab tidak permanen dari blok AV total, yang dapat dikonversi menjadi irama sinus tanpa alat pacu jantung. Pemeriksaan rutin dan koreksi dari hiperkalemia dapat dipertimbangkan sebagai tatalaksana awal alternatif sebelum melakukan pemasangan alat pacu jantung.

\section{INTRODUCTION}

Complete atrioventricular (AV) block or third degree AV block is the complete dissociation between the atrium and the ventricle, which is marked by the complete dissociation between the P wave and QRS complex on the electrocardiography (ECG). ${ }^{1}$ Complete AV block is an emergency related to cardiac arrest if left untreated. ${ }^{2}$ The symptomatic case of complete AV block is a class I (level of evidence: $\mathrm{C}$ ) indication 
for permanent cardiac pacemaker implantation. ${ }^{3}$ However, several reversible cause of complete AV block, such as hyponatremia and hyperkalemia, were reported..$^{4-6}$ Hyperkalemia is a condition of serum potassium $\left(\mathrm{K}^{+}\right)$level $>5.5 \mathrm{mmol} / \mathrm{L}$, while severe hyperkalemia is defined as serum potassium level $>7.5 \mathrm{mmol} / \mathrm{L}^{7}$ High serum potassium levels often impairs the conduction in Purkinje fiber and ventricles. Although AV block may occur, it is one of the rarest presentations of hyperkalemia. ${ }^{5}$ In the previously reported cases of hyperkalemia-induced complete AV block, the cardiac rhythm was converted into sinus after the initial insertion of temporary cardiac pacemaker and the reduction of serum potassium level. ${ }^{4,5}$ Our case was unique since the cardiac rhythm was converted into sinus after the serial correction of severe hyperkalemia (K: $9.5 \mathrm{mmol} / \mathrm{L}$ ) without the insertion of any cardiac pacemaker.

\section{CASE REPORT}

A 56 year old male was admitted to our emergency department with a decrease of consciousness, breathlessness, and vomiting from two days before admission, which had deteriorated since 2 hours before admission. He had a positive history of chronic kidney disease (CKD) without routine hemodialysis. At the time of admission, he was only responded to pain with blood pressure $70 / 50 \mathrm{mmHg}$, heart rate 35 beats per minute, respiratory rate 8 breaths per minute, pulse oximetry $70 \%$, and random blood sugar $137 \mathrm{mg} / \mathrm{dL}$. Endotracheal intubation was performed immediately, followed by mechanical ventilation, to maintain the airway and provide adequate oxygenation. On physical examination, breath sound was vesicular without crackles, wheezing, or any additional breath sound. Cardiac examination showed the regular beat of the first and the second heart sound without murmur. An immediate ECG examination was performed and showed a complete AV block (Figure 1). The Cardiac monitor was placed on the patient. Intravenous fluid, norepinephrine $(0.5 \mathrm{mcg} / \mathrm{kg} / \mathrm{minute})$ and dobutamine (5-10 $\mathrm{mcg} / \mathrm{kg} / \mathrm{minute}$ ) were administered to stabilize the hemodynamic status of the patients.

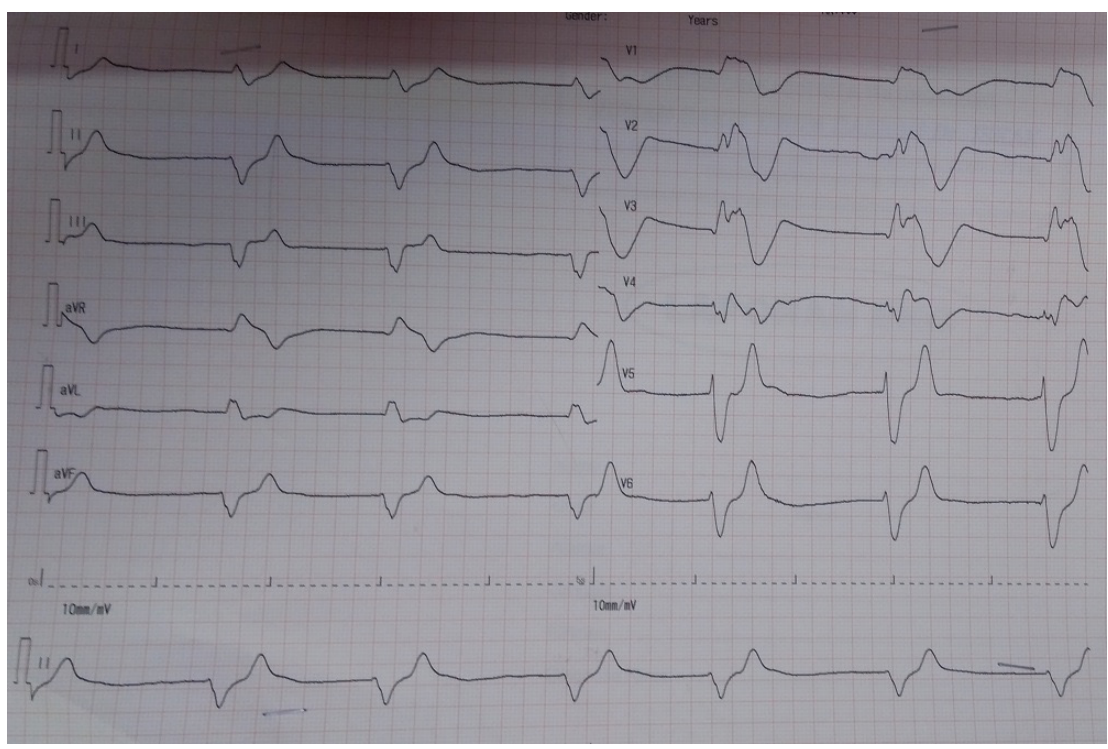

Figure 1. Electrocardiography of the patient at the time of admission.

Arterial blood gas analysis showed metabolic acidosis with $\mathrm{pH}$ 7.08, partial oxygen pressure $\left(\mathrm{PaO}_{2}\right) 118 \mathrm{mmHg}$, partial carbon dioxide pressure $\left(\mathrm{PCO}_{2}\right) 35 \mathrm{mmHg}$, bicarbonate $\left(\mathrm{HCO}_{3}\right)$
$10.4 \mathrm{mmol} / \mathrm{L}$, and base excess (BE) $-18.6 \mathrm{mmol} / \mathrm{L}$. Complete blood count showed normocyticnormochromic anemia with hemoglobin 6.2 $\mathrm{g} / \mathrm{dL}$, mean corpuscular volume (MCV) $95 \mathrm{fL}$, 
mean corpuscular hemoglobin (MCH) $31 \mathrm{pg}$, and hematocrit $18.9 \%$. Renal function test showed $12.89 \mathrm{mg} / \mathrm{dL}$ of serum creatinine and $103 \mathrm{mg} /$ $\mathrm{dL}$ of blood urea nitrogen (BUN). Electrolyte examination showed severe hyperkalemia (9.5 $\mathrm{mmol} / \mathrm{L})$, hyponatremia (123 mmol/L), normal chloride $(96 \mathrm{mmol} / \mathrm{L})$, and hypocalcemia (6.9 $\mathrm{mmol} / \mathrm{L}$ ). Furthermore, 100 meq of bicarbonate sodium, 10 units of insulin, $10 \mathrm{ml}$ of $10 \%$ calcium gluconate, and $50 \mathrm{ml}$ of $40 \%$ dextrose were administered intravenously for the patients to reduce the level of serum potassium. Intravenous bicarbonate sodium also administered for the correction of a metabolic acidosis of the patient. The administration of $10 \%$ calcium gluconate, insulin, and $40 \%$ dextrose was performed three times. The hemodynamic status and the level of consciousness of the patient were improved gradually.
Five hours after the admission, the patient was responded to verbal stimulation with blood pressure 130/90, heart rate 92 beats per minute, spontaneous respiratory rate 16 breaths per minute, and pulse oximetry $99 \%$. The ECG evaluation was performed and showed normal sinus rhythm (Figure 2). The evaluation of electrolyte examination showed serum potassium $5.9 \mathrm{mmol} / \mathrm{L}$, sodium $130 \mathrm{mmol} / \mathrm{L}$, calcium $7.4 \mathrm{mg} / \mathrm{dL}$, and chloride $94 \mathrm{mmol} / \mathrm{L}$. The evaluation of arterial blood gas analysis showed $\mathrm{pH} 7.3, \mathrm{PaO}_{2} 139 \mathrm{mmHg}, \mathrm{PCO}_{2} 19 \mathrm{mmHg}, \mathrm{HCO}_{3}$ $9.8 \mathrm{mmol} / \mathrm{L}$, and BE - $14.1 \mathrm{mmol} / \mathrm{L}$. Furthermore, the patient was prepared for hemodialysis. He was extubated and was admitted to a high care unit (HCU) after hemodialysis for the rest of the treatment. The patient was discharged from the hospital 7 days later without any problems.

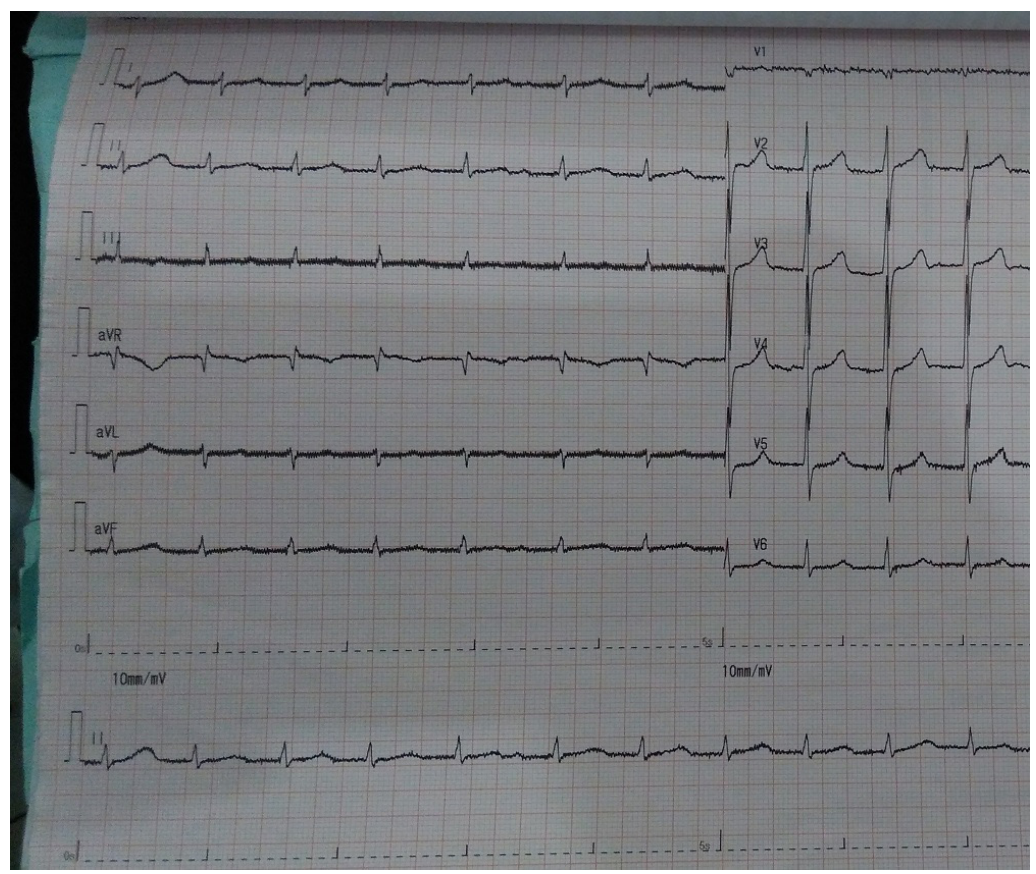

Figure 2. Electrocardiography of the patient 5 hour after the time of admission.

\section{DISCUSSION}

Complete AV block can occur due to several clinical disorders, either structural or functional. Structural changes due to coronary artery disease, infection, congenital heart disease, inflammatory disease, and neoplasm are generally causing permanent AV block. On the other hand, functional disturbance due to autonomic, metabolic, and drugs, which are related to AV block, may be reversible. ${ }^{1}$ The guideline by American College of Cardiology/American Heart Association (AHA) still recommends the 
implantation of permanent cardiac pacemaker as the treatment of the complete AV block and the advanced second degree AV block at any anatomic level, if associated with symptomatic bradycardia (including heart failure) and ventricular arrhythmia presumed to be due to AV block (recommendation class I, level of evidence C). ${ }^{3}$ However, our case demonstrated the successful conversion of complete AV block to sinus rhythm without the insertion of any cardiac pacemaker.

Kim et al. reported the conversion of complete AV block into sinus rhythm in a patient with severe hyperkalemia (initial K: $7.9 \mathrm{mmol} / \mathrm{L}$ ), after the insertion of temporary percutaneous cardiac pacemaker and the correction of hyperkalemia (corrected K: $5.03 \mathrm{mmol} / \mathrm{L}$ ). ${ }^{4}$ Baratloo et al. reported similar case of a patient with severe hyperkalemia (initial K: $8 \mathrm{mmol} / \mathrm{L}$ ), metabolic acidosis (pH: 7.23), and complete AV block, who had his cardiac rhythm converted into sinus, after the initial insertion of temporary transcutaneous cardiac pacemaker, correction of hyperkalemia, and hemodialysis. ${ }^{5}$ In current report, we report a patient with symptomatic complete AV block, severe hyperkalemia (initial $\mathrm{K}: 9.5 \mathrm{mmol} / \mathrm{L}$ ), and metabolic acidosis (pH: 7.08), who had his cardiac rhythm converted into sinus after the reduction of serum potassium (corrected $\mathrm{K}: 5.9 \mathrm{mmol} / \mathrm{L}$ ) without the insertion of any cardiac pacemaker. In addition, compared to the patients from the previous reports, our patient had the worse initial clinical condition (decrease of consciousness and severe hypotension), the higher level of serum potassium, and worse metabolic acidosis. He also did not undergo hemodialysis before the conversion of his cardiac rhythm back to the sinus. This case illustrates that even in the worse clinical situation and worse metabolic disturbance, the correction of hyperkalemia might resulting in the conversion of complete AV block into sinus rhythm without either the insertion of cardiac pacemaker or hemodialysis.

Hyperkalemia is a prevalent and potentially life-threatening electrolyte disturbance. ${ }^{7}$ This condition can produce a gradual decrease in excitability and conduction velocity of pacemaker cells and other conducting tissue in the heart. These impairments frequently affects the conduction in Purkinje fibers and ventricles. Impairment of atrioventricular conduction may occur on the rarest occasion. ${ }^{4,5}$ In our case, hyperkalemia might be occurred due to the CKD and the metabolic acidosis. Reduced glomerular filtration rate leads to the decreased of kidney excretion of potassium, while metabolic acidosis cause potassium shift from the intracellular to extracellular space. ${ }^{7}$ Therapy for this condition including intravenous $10 \%$ calcium gluconate to stabilize the membrane potential and improved the cardiac symptom; intravenous insulin with/ without dextrose infusion and bicarbonate sodium to increase the potassium shift from extracellular to intracellular space; and loop diuretics or hemodialysis to increase potassium excretion. Bicarbonate sodium is preferably given to patients with metabolic acidosis. ${ }^{7}$ In our case, serial correction of potassium using $10 \%$ calcium gluconate, insulin, $40 \%$ dextrose, and a single dose of 100 meq bicarbonate sodium improved the cardiac symptoms of the patients and significantly reduced the serum potassium level. Hemodialysis was performed to treat other metabolic disturbances and to provide further control of serum potassium.

Furthermore, other associated metabolic abnormalities, such as metabolic acidosis and hyponatremia in our patient also reported being the cause of complete AV block. ${ }^{1,6}$ However, in our case, the conversion of the cardiac rhythm into sinus has occurred when the metabolic acidosis and hyponatremia were still uncorrected (pH: 7.3; sodium: $130 \mathrm{mmol} / \mathrm{L}$ ). Based on these findings, routine examination and correction of any potentially related metabolic disturbance, especially hyperkalemia, can be considered as the alternative initial management of complete AV block, prior to the insertion of a cardiac pacemaker. It also can be considered in health facilities, where the cardiac pacemaker is not available. Although it was reported to produce a good result, more studies with larger subjects are needed to confirm these findings. 


\section{CONCLUSION}

Hyperkalemia can be a reversible cause of complete AV block in a patient with chronic kidney disease. The correction of hyperkalemia might be resulting in the conversion of complete $\mathrm{AV}$ block into sinus rhythm without the insertion of any cardiac pacemaker. Routine examination and correction of hyperkalemia can be considered as the alternative initial management of complete $\mathrm{AV}$ block, prior to the insertion of a cardiac pacemaker.

\section{CONFLICT OF INTEREST}

None declare.

\section{ACKNOWLEDGEMENT}

The author would like to thank Elsa Yunita for her help in the making of this article.

\section{REFERENCES}

1. David DS, Gordon FT. Bradyarrhythmias. In: Harrison's principles of internal medicine 18th ed. Mc Graw Hill Professional. 2011.

2. Sheyin 0, Mgbemena M, Magnus-lawson 0, Salahudeen L. High grade atrioventricular block presenting with cardiac arrest. American Journal of Cardiovascular Disease Research. 2014;2(2):31-5.

3. Epstein AE, DiMarco JP, Ellenbogen KA, Estes NAM, Freedman RA, Gettes LS, et al. ACC/ AHA/HRS 2008 guidelines for device-based therapy of cardiac rhythm abnormalities. Journal of the American College of Cardiology. 2008;51(21):e1-62.

4. Kim N-H, Oh SK, Jeong J-W. Hyperkalaemia induced complete atrioventricular block with a narrow QRS complex. Heart. 2005;91(1):e5-e5.

5. Baratloo A, Haroutunian P, Rouhipour A, Safari S, Rahmati F. Hyperkalemia-induced complete heart block. Journal of Emergency Practice and Trauma. 2015;1(1):35-8.

6. Badrinath, Suresh K, Ragunathan R, Babu SS. A case report of complete atrioventricular heart block due to hyponatremia. Heart India. 2017;5(2):105.

7. Lehnhardt A, Kemper MJ. Pathogenesis, di- agnosis and management of hyperkalemia. Pediatric Nephrology. 2011;26(3):377-84. 